Etnográfica

Revista do Centro em Rede de Investigação em

Antropologia

vol. 25 (1) | 2021

Vol. 25 (1)

\title{
Os Moinheiro da Caála: a micro-história de uma família madeirense na colonização, descolonização e retorno de Angola
}

The Moinheiro from Caála: the microhistory of a Madeiran family in the colonization, decolonization and return from Angola

\section{Elsa Peralta e Bruno Góis}

\section{(2) OpenEdition}

\section{Journals}

\section{Edição electrónica}

URL: https://journals.openedition.org/etnografica/8788

DOI: 10.4000/etnografica.8788

ISSN: 2182-2891

\section{Editora}

Centro em Rede de Investigação em Antropologia

\section{Edição impressa}

Paginação: 47-72

ISSN: 0873-6561

\section{Refêrencia eletrónica}

Elsa Peralta e Bruno Góis, «Os Moinheiro da Caála: a micro-história de uma família madeirense na colonização, descolonização e retorno de Angola», Etnográfica [Online], vol. 25 (1) | 2021, posto online no dia 05 março 2021, consultado o 28 janeiro 2022. URL: http://journals.openedition.org/etnografica/ 8788 ; DOI: https://doi.org/10.4000/etnografica.8788

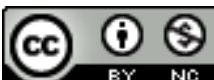

Etnográfica is licensed under a Creative Commons Attribution-NonCommercial 4.0 International License. 


\section{Os Moinheiro da Caála:}

\section{a micro-história de uma família} madeirense na colonização, descolonização e retorno de Angola

\section{Elsa Peralta e Bruno Góis}

Este artigo é a micro-história de uma família de colonos madeirenses em Angola, desde o momento em que se instalaram no planalto da Huíla, em finais do século XIX, até à descolonização, em 1975. Com recurso a testemunhos, pesquisa de arquivo e investigação bibliográfica, esta é uma história-memória, que parte da experiência vivida de uma família particular para alcançar uma relação com as estruturas sociais, políticas e históricas mais vastas que marcaram a história da colonização e da descolonização portuguesas. Focando-nos numa família portuguesa de descendentes de colonos do século XIX, composta por gente dos pequenos negócios e trabalhadores, devolvemos a estes outliers o seu lugar na história dos colonos brancos e problematizamos a classe, o género e as relações raciais na sociedade colonial.

PALAVRAS-CHAVE: colonização, descolonização, retorno, Angola, memória, micro -história.

The Moinheiro from Caála: the microhistory of a Madeiran family in the colonization, decolonization and return from Angola - This article is the microhistory of a family from Madeira who moved to Angola, from the time they settled in the highlands of the Huila in the late nineteenth century to the decolonization process in 1975. With the use of testimonies, archival research and bibliographic research, this is a history-memory of the lived experience of a particular family. Its purpose is to achieve an understanding of the wider social, political and historical structures that marked the history of Portuguese colonization and decolonization. Focusing on a Portuguese family of nineteenth-century settlers' descendants, people of the small business and working class, we give these outliers their place in the history of white settlers and problematize class, gender, and race relations in colonial society.

KEYWORDS: colonization, decolonization, return, Angola, memory, microhistory.

PERALTA, Elsa (elsa.peralta@campus.ul.pt) - Centro de Estudos Comparatistas, Universidade de Lisboa, Portugal.

GÓIS, Bruno (brunodegois@gmail.com) - Instituto de Ciências Sociais, Universidade de Lisboa, Portugal. 


\section{NECESSÁRIO PREÂMBULO}

Uma micro-história está no centro deste artigo. ${ }^{1}$ Essa história segue a trajetória dos descendentes do madeirense António de Freitas Moinheiro, o primeiro da sua linhagem a estabelecer-se em Angola. Mas esta não é apenas a história de uma família. É também a da colonização e da descolonização portuguesas, desde a chegada dos primeiros colonos às terras altas do Sul de Angola ainda no século XIX, até às consequências da descolonização, que se estendem muito para além do quadro temporal das independências africanas e do retorno de nacionais à antiga metrópole em 1975. É uma história de deslocamentos e de migrações, de violência e de exploração, de privilégio e de pobreza, de "raça", de género e de classe.

$\mathrm{Na}$ linha de estudos consagrada a partir da microstoria italiana, inaugurada por Giovanni Levi (1991) e Carlo Ginzburg (1993), propomos um exercício intensivo de investigação histórica de uma família e da sua trajetória migratória desde o último quartel do século XIX. Centramo-nos num ramo familiar que se desenvolveu na Caála, Huambo, no Sul de Angola, e depois se dispersou com a descolonização. A reconstituição familiar é uma ferramenta valiosa para abordar grandes questões históricas e sociais (Tilly e Cohen 1982). Com esta abordagem pretendemos articular o particular/individual/local com o geral/ social/global. Com efeito, o caráter particular das biografias, na sua capacidade de problematizar generalizações, não é incompatível com o reconhecimento de uma ligação umbilical à história social, pois a individualidade é sempre uma "individualidade social" (Burkitt 2008: 192). Diferentes "formas históricas de individualidade" formam-se e transformam-se através da história, marcadas pelas potencialidades e pelos constrangimentos de cada época e de cada sociedade (Sève 2008: 461-463). A longa tradição antropológica de escrita de biografias individuais (e.g. Turner 1960; Mintz 1974 [1960]; Crapanzano 1980), segundo a qual múltiplas conexões são estabelecidas entre as pessoas e as suas histórias, fornece também evidência das muitas potencialidades do método biográfico na complexificação da história social.

É também esse o propósito deste texto. A família Freitas Moinheiro não é importante em si mesma, nem teve qualquer influência nos processos globais do colonialismo e da descolonização. António de Freitas Moinheiro era apenas um jovem trabalhador, filho de um fazendeiro que, tal como outros, tomou a decisão, nos finais do século XIX, de partir para Angola acompanhando as transformações em matéria de política colonial. Moinheiro é um mero apontamento

1 A investigação que serviu de base à elaboração deste texto foi realizada no âmbito dos projetos "Narratives of loss, war and trauma: Portuguese cultural memory and the end of empire" (IF/01530/2014) e "Portuguese colonial empire and urban popular culture: comparing visions from the metropolis and the colonies (1945-1974)” (PTDC/CPC-CMP/2661/2014), financiados pela Fundação para a Ciência e a Tecnologia (FCT). 
na memória dos seus descendentes, um registo desbotado em velhos arquivos, ausente das páginas dos livros de História. A sua história é útil não tanto por ser significativa em si mesma, mas porque oferece um outro vislumbre de uma história global que, frequentemente, escapa às grandes classificações macro -históricas (Andrade 2011).

Esta micro-história visa, assim, complexificar as generalizações em torno de indivíduos médios e devolver aos outliers (Magnússon 2003: 710 ) o seu lugar na história. No caso dos migrantes da colonização portuguesa, encontrar os outliers implica fragmentar o universo de pesquisa, na busca por identificar "a lógica mais profunda do mundo social", a qual "pode ser apreendida desde que mergulhemos na particularidade de uma realidade empírica, historicamente localizada e datada" (Bourdieu 1991: 628). No seio de uma população classificada como retornada, contabilizada em cerca de 500.000 indivíduos que chegaram à antiga metrópole entre 1974 e 1979 (Pires 1987), desenharam-se quadros de vida díspares. Na sua grande parte, haviam integrado a ampla vaga migratória da fase final do colonialismo português. Mas uma minoria, como a família que aqui estudamos, pertencia a uma vaga de colonização antiga, chegada a África no quadro de projetos de colonização oficial de Angola de finais do século XIX. Enquanto muitas dessas pessoas eram originárias de distritos do interior e de vocação agrícola, outras eram oriundas de centros urbanos e detinham capitais sociais mais elevados (Castelo 2017). Todas estas heterogeneidades foram subsumidas nas classificações únicas e abrangentes de "colono" ou de "retornado", fazendo esquecer que nas margens destas generalizações existem hierarquias raciais, de classe e de género, com uma influência significativa nas condições materiais, quer das migrações coloniais, quer das migrações do retorno e reintegração na ex-metrópole (Peralta 2019).

Com a história da família Moinheiro pretendemos dar conta dessas margens, centrando-nos numa família da colonização mais antiga, que socialmente tem as mesmas características dos migrantes económicos: colonos agrícolas, gente que estabelece pequenos negócios, trabalhadores. A sua posição social, favorecida em relação à população local, por ser de origem europeia numa sociedade colonial, não é a mesma das famílias de grandes proprietários agrícolas ou industriais, com capacidade de deter propriedade e capital na colónia e na metrópole, nem é a mesma de outros trabalhadores e pequenos proprietários da colonização mais recente, com laços familiares e sociais mais estreitos com a então metrópole. Essas diferenças vão marcar as trajetórias de vida dos indivíduos desta família, quer durante o período colonial, quer nas suas estratégias de reintegração social após a descolonização. Procuramos, desta forma, evidenciar que a estrutura da sociedade colonial, embora fundada em classificações raciais, não deixou também de ser marcada por consideráveis diferenças de género e de classe. Como evidencia Painter em The History of White People (2010), o conteúdo e a amplitude do conceito de branco variam ao longo 
do tempo. As classificações raciais resultam de processos sociopolíticos que procuram biologizar hierarquias sociais, pelo que as condições laboral e de cidadania condicionam os processos de racialização. Como analisou Bastos (2008), as autoridades coloniais administrativas e médicas chegaram a considerar os madeirenses da Huíla como inferiores e inaptos para a colonização, ao passo que, anos mais tarde, os propagandistas do colonialismo lhes vieram a chamar pioneiros. Ao evidenciarmos as trajetórias de vida da família Moinheiro, pretendemos problematizar esta interseção entre raça, género e classe na sociedade colonial e romper com a homogeneização do universo da população colona branca.

Alcançar o objetivo que aqui nos propomos comporta vários desafios metodológicos e epistemológicos. Desde logo porque parte desta micro-história é reconstruída a partir das memórias dos indivíduos ainda vivos que nela participaram ou dos seus descendentes. Os seus relatos comportam muitas distorções factuais em relação ao passado, são atravessados por várias contradições, e também por omissões e esquecimentos. Estes desafios são tanto maiores pelo facto de a família em estudo ser a família de Bruno Góis, um dos autores deste texto. Trazendo benefícios de acesso de vária ordem, esta proximidade traz também uma exigência acrescida de distanciamento e objetividade. Por esse motivo, as entrevistas foram realizadas conjuntamente pelos dois autores a vários membros da família em estudo, por vezes individualmente, e outras vezes em grupo, e foram acompanhadas também da observação de momentos de sociabilização familiar. Foram entrevistados membros desta família residentes em Portugal, membros da família imigrantes nos Estados Unidos e outros que permaneceram em Angola após a independência, aproveitando a sua vinda a Portugal. ${ }^{2}$ Também foram realizadas várias conversas informais com membros e amigos da família. ${ }^{3}$ Interações com membros do grupo fechado de Facebook Chibia proporcionaram a identificação de fotografias e o contacto com alguns membros da família. Para além destes momentos de interação, esta micro-história está sustentada em pesquisa no Arquivo Histórico Ultramarino (AHU), no Arquivo Histórico da Marinha (AHM) e no Arquivo Regional da Madeira (ARM).

2 Residentes em Portugal: Maria José Munheiro, a sua irmã Maria Ermelinda e o seu genro Alberto, ex-marido da filha mais velha; residentes nos Estados Unidos: as filhas de Maria José Munheiro, Maria Filomena e Isabel, e o marido desta última; residentes em Angola: Isabel, a cunhada de Maria José Munheiro e esposa do seu irmão António.

3 Merecem destaque as conversas com Leonel de Freitas Amador e Maria Helena Fontes, ambos primos de Maria José Munheiro e ex-residentes da Chibia, e com Maria Salomé Rosa, uma vizinha da família que residiu quer na Chibia, quer na Caála. 
DA MADEIRA AO SUL DE ANGOLA:

\section{A CHEGADA DOS PRIMEIROS COLONOS}

A história da ilha da Madeira é fortemente marcada pelas migrações. Desde o início da colonização foram uma constante na vida do arquipélago, a par com a sua importância estratégica para as trocas transoceânicas e para as redes intraimperiais. A micro-história da família madeirense que aqui trazemos é, como tantas outras, uma história de dispersão, sendo, por isso, uma janela aberta para essa história mais geral das migrações atlânticas e para a vida social nos territórios de partida e de chegada. É a história da família Moinheiro, apelido que é circunscrito a uma linhagem de descendentes de madeirenses passível de ser identificada. O documento mais antigo onde encontramos o nome da família Moinheiro data de 1856: é a averiguação de bens pelo falecimento de José de Freitas, "o Moinheiro", que significa dono ou trabalhador do moinho (moleiro ou moageiro). Nesse documento, recuperado no Arquivo Regional da Madeira, constam os nomes da viúva Joana Maria, dos filhos Maria Joana, Manuel, José e Francisco. ${ }^{4}$ Descobrimos, cruzando outros documentos nesse arquivo (registos de batismos, casamentos, passaportes) ${ }^{5}$ com os arquivos online da imigração nos EUA e com documentos oficiais brasileiros, que houve descendentes que rumaram para o estado de Massachusetts ${ }^{6}$ no início do século XX, e que outros parentes emigraram para o Brasil. ${ }^{7}$ Porém, o percurso que vamos acompanhar é o de António de Freitas Moinheiro, filho de Francisco de Freitas (Moinheiro) e de Jesuína do Nascimento, pois é essa micro-história que nos abre o horizonte da colonização, descolonização e retorno de Angola.

António de Freitas Moinheiro, natural da Madeira, foi o primeiro elemento da sua família a pisar terras angolanas. Nascido em 1873 no concelho de Santa Cruz, embarcou no Funchal rumo a Angola e estabeleceu-se na colónia da Chibia, no planalto da Húla. Baseados nos relatos familiares, presumimos

$4 \quad C f$. autos cíveis de inventário obrigatório, inventariante Joana Maria, viúva de José de Freitas "O Moinheiro", Juízo Ordinário e Órfãos do Julgado de Santa Cruz da Comarca Oriental do Funchal, livro n. ${ }^{\circ}$ 129, PT-ABM-JUD-2963-12, Arquivo Regional da Madeira, 1856/1857.

5 Cf. documentos no ARM: Batismo de António, Pai: Francisco de Freitas; Mãe: Jesuína do Nascimento, 30-12-1873, Paróquia de Santa Cruz, livro 2499-A, folha 44, número 129; Administração do Concelho do Funchal, Listas dos Passageiros Saídos, livro n. ${ }^{\circ}$ 129, PT-ABM-GCFUN-129, 112v e 113, 1891; Casamento: António de Freitas c. Maria Rodrigues Correia, 06-04-1891, Paróquia de Santa Maria Maior - Funchal, livro 2143 , folhas $7 v^{\circ}-8 v^{\circ}$, n. ${ }^{\circ} 9$.

6 José de Freitas Moinheiro e a sua esposa Lucrécia Augusta de Jesus chegaram a Boston em 13 de fevereiro de 1916 a bordo do navio Canopic. Outros Moinheiro aparecem nos registos de entrada nos EUA. Cf. Massachusetts, Boston Passenger Lists, 1891-1943 238 - v. 387 Feb 11, 1916 - Feb 29, 1916, digitalização disponível em < https://www.familysearch.org/ark:/61903/3:1:33S7-9Y7R-J37?i=472\&cc $=1923995>$ (última consulta em maio de 2020).

7 Em 1940 foi publicada no Diário Oficial da União a naturalização do português João de Freitas Moinheiro, nascido em 1898, como cidadão brasileiro. Cf. Brasil, DOU, l de julho de 1940, secção 1 , pp. 13-14. 
que António tenha feito parte desse contingente de madeirenses que a política de colonização oficial dirigiu para as cobiçadas terras altas do Sul de Angola, numa altura em que as diferentes potências coloniais disputavam a hegemonia sobre o continente africano. A estes colonos madeirenses da Huíla, como foi o caso dos Moinheiro, foi dado pela população africana o nome de "chicoronhos" para os distinguir dos outros portugueses, um nome que ganhou o significado de "colono rude do Sul", uma distinção que sugere uma racialização diferenciada entre os portugueses das colónias (Bastos 2008).

Partimos, então, à procura de uma lista de embarcados, no Arquivo Histórico da Marinha e no Arquivo Histórico Ultramarino. Chegámos a pensar que António poderia ter sido um dos embarcados no navio Índia, ainda pequeno, junto com os mais de duzentos madeirenses que, em 1884, rumaram ao porto de Moçâmedes e dali subiram o planalto com carros de boers para fundarem, em 19 de janeiro de 1885, a colónia do Lubango, depois Sá da Bandeira (Bastos 2008). Várias hipóteses se abriam: será que do Lubango foi deslocado para a colónia da Chibia, a pouco mais de 40 quilómetros de distância? Ou será que integra o segundo grupo de madeirenses, identificado por Medeiros (1976) no seu estudo sobre a colonização da Huíla, chegado a Moçâmedes em julho de 1885? Deste contingente, 31 famílias ficaram no Lubango, 19 foram para a Humpata e 12 para a Chibia; estas últimas constituíam um grupo de 34 pessoas, que se juntou a três moradores portugueses já lá estabelecidos e a alguns boers. Será que António integrava este grupo? Ou será que fazia parte de algum outro contingente de madeirenses embarcados entre 1884 e 1892, ano em que terminou a migração oficial para Angola, que, de acordo com Mendonça (1951: 36), constituiu uma população de pouco mais de mil madeirenses no Sul de Angola?

Eram hipóteses em aberto. A única certeza que a história familiar nos dava era que António de Freitas Moinheiro vivia na Chibia em 1896, ano em que nasceu o seu filho Jaime de Freitas Moinheiro. Maria José, filha de Jaime, contou-nos que o seu avô António partiu da Madeira para Angola sem família constituída, e que a sua avó paterna, de nome Maria José, como a neta, era "francesa" da África do Sul (ver figura 1). Não lhe conhecia o nome de solteira. Também especulámos sobre a origem e o percurso desta "francesa" da África do Sul. Seria ela uma descendente dos huguenotes franceses estabelecidos na África do Sul que mais tarde viriam a procurar o planalto angolano para fugir ao controlo britânico? Será que ela fazia parte desses boers estabelecidos na Chibia de que Medeiros fala? Nada o comprovava, restava apenas a ideia de que teria uma origem estrangeira.

Já um outro neto de António, chamado Leonel de Freitas Amador, atualmente residente no Algarve, contou-nos que os avós tinham casado muito jovens, ainda na Madeira, precisamente para poderem embarcar. Contou ainda que da Madeira para o Sul de Angola foram "três irmãos", mas que "os outros 


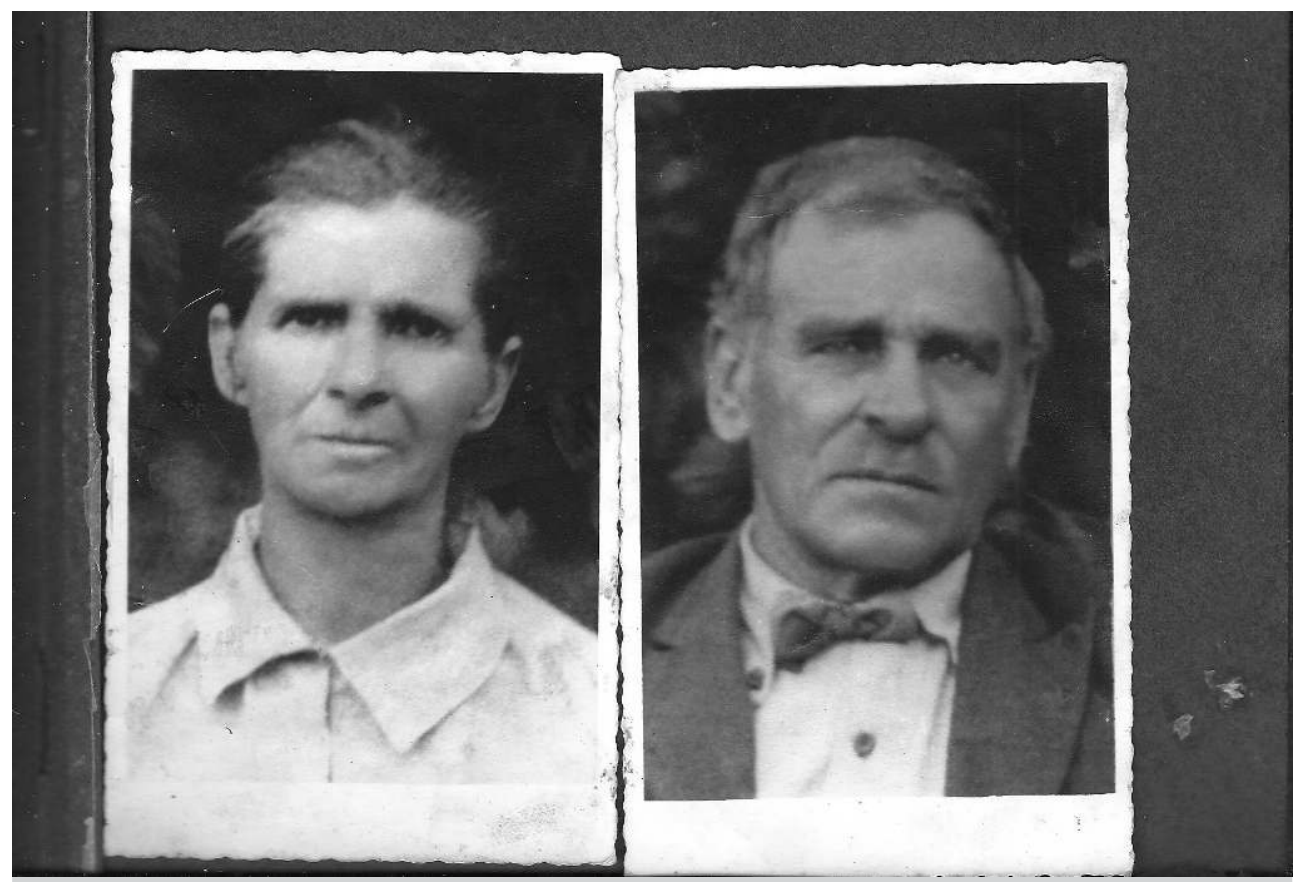

Figura 1 - António de Freitas Moinheiro (n. 1873) e sua mulher Maria José Rodrigues Correia (n. 1875), Angola, s/data, pormenor de álbum familiar trazido da Caála para Portugal, em 1975, pela nora Maria Adelaide. Fonte: arquivo pessoal.

não gostaram daquilo e foram-se embora". Através de pesquisa no ARM, conseguimos descobrir que António de Freitas Moinheiro e Maria José Rodrigues Correia casaram ainda no Funchal em 1891: ele, filho de lavradores, era um trabalhador com 18 anos; ela tinha 16 anos e era lavadeira. ${ }^{8}$ Diz-nos o mesmo registo paroquial católico que, por não terem meios para o fazer, foram dispensados de pagar os autos do casamento. E terão rumado a Angola nesse mesmo ano. Descobrimos então que a "francesa da África do Sul” era afinal uma madeirense nascida na América do Sul, mais precisamente em Demerara, na então Guiana Britânica e atual República da Guiana. A Guiana era um dos principais destinos da emigração madeirense na primeira metade do século XIX, inicialmente para trabalhar nas plantações do açúcar e depois também no comércio. Entretanto, a migração para esse território foi decaindo principalmente a favor do Brasil e, temporariamente, de Angola e dos EUA (Menezes 1995; Ferreira 2006; Cosme 2007). Essa circulação intercontinental era frequente, como pudemos verificar nos registos de embarcados no Funchal. Nos barcos que retornavam da Guiana, ou que para lá de novo levavam migrantes,

8 Cf. Casamento: António de Freitas c. Maria Rodrigues Correia, 06-04-1891, Paróquia de Santa Maria Maior - Funchal, livro 2143 , folhas $7 v^{\circ}-8 v^{\circ}$, n. ${ }^{\circ} 9$. 
iam dezenas de pessoas com nomes portugueses, mas batizadas ou casadas na Guiana Britânica.

Todos os meses, geralmente no dia 8, passava no porto do Funchal um vapor para África. No dia 9 de agosto de 1891, o vapor português Ambaca sai do Funchal rumo a África, levando entre os passageiros "F. de Freitas Moinheiro, mulher e 7 filhos". Nos registos de embarcados para África, foram os únicos Moinheiro que encontrámos (figura 2). Talvez o jovem casal tenha sido registado à saída no rol dos filhos de Francisco de Freitas Moinheiro, pai de um e sogro da outra. Conforme pudemos verificar no ARM, os registos para as colónias são mais imprecisos e incompletos do que os das partidas para o Brasil, que aliás se destacam, com barcos maiores e sempre com uma centena ou duas de madeirenses que partiam para não mais voltar.

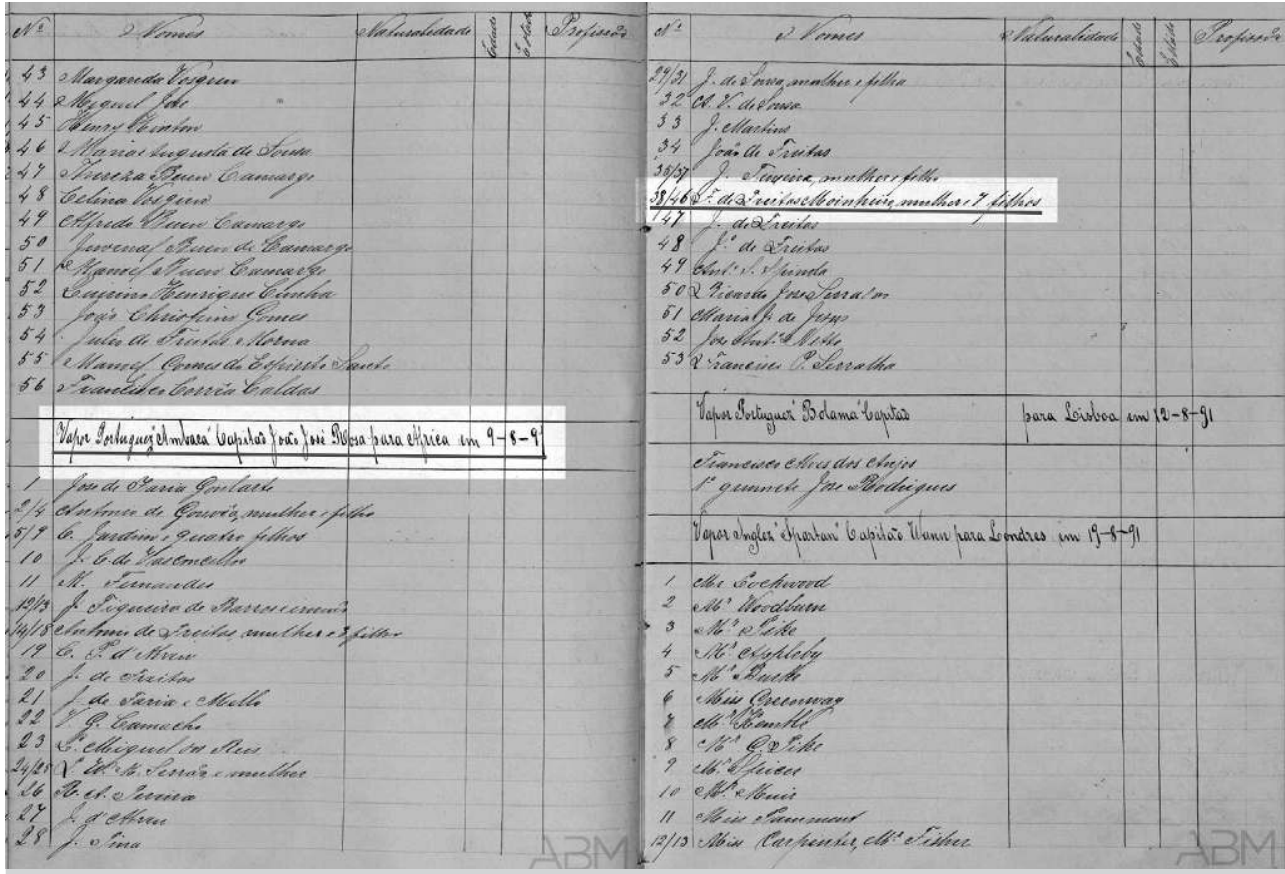

Figura 2 - Lista de embarcados no Funchal no vapor Ambaca rumo a África a 9 de agosto de 1891, onde constam "F. de Freitas Moinheiro, mulher e 7 filhos".

Fonte: Arquivo Regional da Madeira, Administração do Concelho do Funchal, Listas dos Passageiros Saídos, livro n. ${ }^{\circ}$ 129, PT-ABM-GCFUN-129, $112 \mathrm{v}$ e 113.

\section{DA HUÍlAA AO HUAMBO: MIGRAÇÕES INTERNAS NAS COLÓNIAS}

António de Freitas Moinheiro e Maria José Rodrigues Correia estabeleceram-se na Chibia, onde tiveram sete filhos. Sair da Madeira e estabelecer-se como colonos agrícolas na Huíla proporcionou-lhes meios para se desenvolverem 
como família - afinal, como vimos, a sua situação financeira na ilha era tal que tiveram de ser dispensados de pagar o casamento. Na Húla tinham uma quinta, onde produziam para a própria subsistência (figura 3). Construíram a casa e nos campos cultivavam trigo, milho e cevada e também muitas árvores de fruto. Criavam galinhas, patos e gansos. Conforme cresceram, os filhos foram casando e saindo de casa e da Chibia. Uns para perto, para o Lubango, outros para várias partes de Angola ou, até, para Moçambique. Seguiram o curso do desenvolvimento colonial.

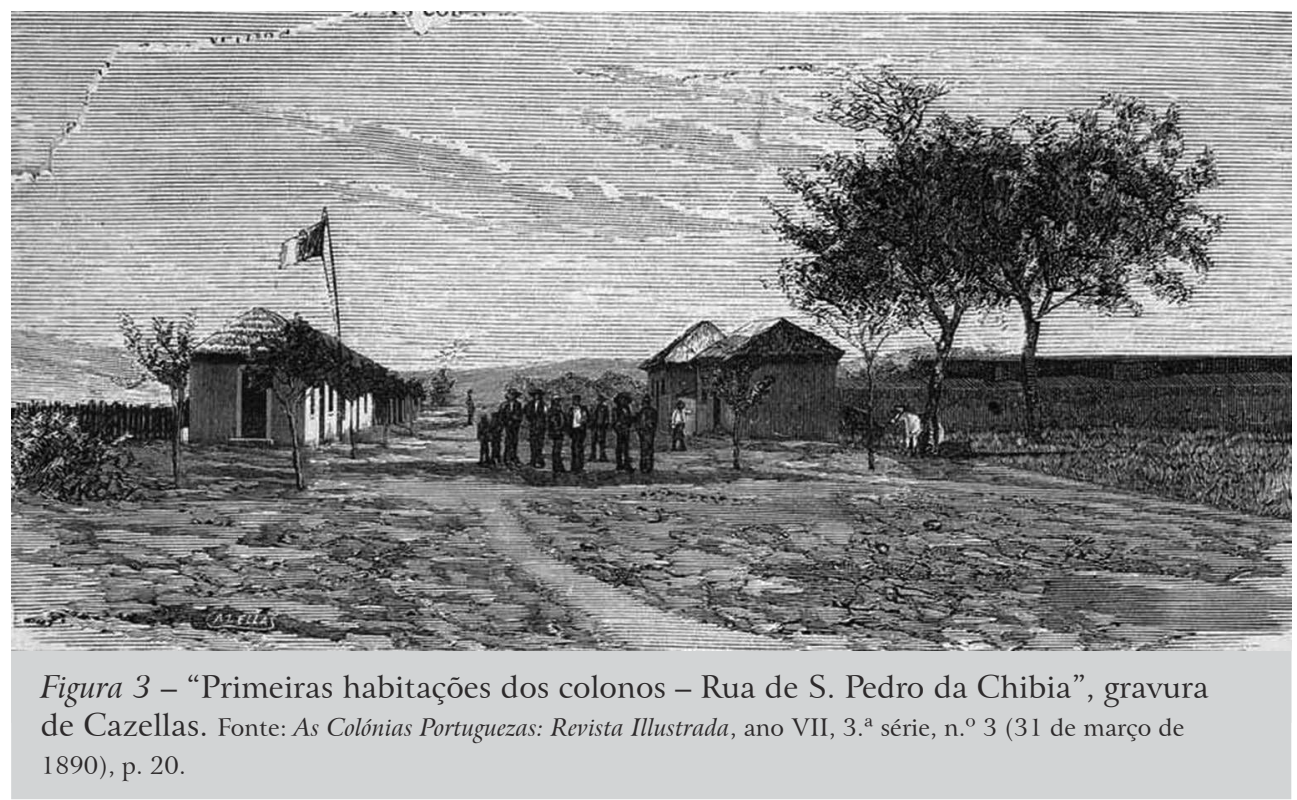

Um dos filhos, Jaime (figura 4), nascido em 18 de julho de 1896, começou a ganhar a vida ainda jovem a fazer o transporte de mercadorias e mantimentos entre o Sul e o interior de Angola, nos carros que os boers tinham introduzido no território como vitais nas vias de comunicação. Jaime levava seis meses para lá e seis meses para cá. Até que numa dessas viagens assentou na Caála, uma localidade próxima da cidade do Huambo (Nova Lisboa entre 1928 e 1975), a mais de 400 quilómetros a nordeste da Chibia. Parte da família permaneceu na Chibia, enquanto um novo ramo se estabeleceu mais para o interior, na Caála. Aqui o apelido Moinheiro muda, aquando do registo paroquial da geração aí nascida, para Munheiro, e enfraquecem os contactos entre os dois ramos da mesma família presentes em Angola.

A colonização de Angola encaminhava-se para o interior do continente, seguindo a expansão do caminho-de-ferro, que se desenvolvia, desde 1887, a partir de três linhas ferroviárias: as de Luanda, Moçâmedes e Benguela. Esta última fora iniciada em 1899 pelo governo português, para dar acesso 
ao interior e permitir que o cobre das minas da província congolesa de Catanga pudesse ser transportado para os portos atlânticos e daí para a Europa. O interesse dos britânicos neste empreendimento corria a par com a incapacidade do governo de Lisboa para the dar continuidade. Em 1902 o Estado português outorgou a construção e a exploração por 99 anos do caminho-de-ferro de Benguela ao engenheiro escocês Robert Williams. ${ }^{9}$ Em 1912 a ferrovia já ligava as cidades portuárias do Lobito e Benguela ao Huambo, a 423 quilómetros para o interior, e em 1929 chegava a Luau, na fronteira com o Congo. Mas a progressão era lenta, e com avultados custos para o magnata britânico, que acabaria por perder o controlo das minas de cobre a favor da Société Générale de Belgique.

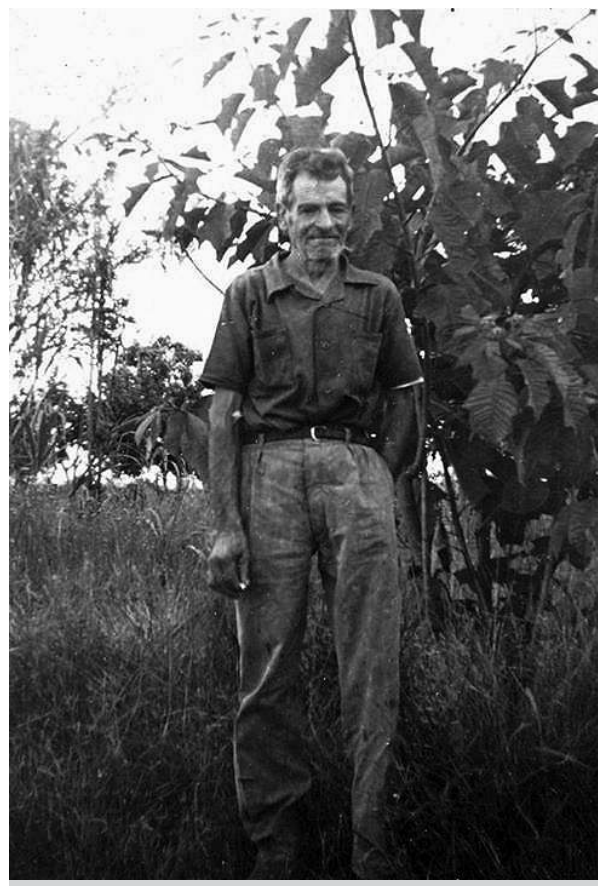

Figura 4 - Jaime de Freitas Moinheiro (n. Chibia 1896), s/data.

Fonte: arquivo pessoal.

A chegada do comboio na década de 1910 ao planalto central de Angola permitiu uma viragem da produção da borracha, cujo preço caíra, para a produção de milho, marcando o desenvolvimento agrícola da região. Entretanto, prosseguiam as conquistas do interior, visando a submissão total dos reinos africanos, e as ameaças alemãs (e secretamente também britânicas) ao domínio português sobre aqueles territórios. A colonização dirigida e planeada por Norton de Matos (1912-1915 e 1921-1923), com base na agricultura e na pesca, acabaria por fracassar e a crise da economia colonial empurrou muitos colonos de origem madeirense para as cidades, sobrevivendo da caridade. Em meados dos anos 20, crescia o número de brancos pobres nos planaltos do Sul - um décimo da população branca de Angola não tinha meios de subsistência (Clarence-Smith 1990 [1985]). Este aspeto deve ter contribuído para que muitos colonos, como Jaime, se aventurassem pelo interior à procura de melhores oportunidades. $\mathrm{Na}$ Caála, Jaime parece ter tido todas as profissões. Conforme nos contam, foi ferreiro, marceneiro, carpinteiro, serralheiro e mecânico de carroças, e montou uma oficina. 
Apesar de os republicanos terem chegado ao poder com reivindicações colonialistas (em crescendo desde o Ultimatum inglês de 1890), as crises económicas, os défices crónicos dos planos de fomento dos cônsules gerais de Angola e as pressões da Primeira Guerra Mundial fizeram com que, no final do regime republicano, se erguesse na metrópole uma coligação social dos afetados pelo declínio do império que contribuiria para a instauração da Ditadura Militar de 1926 (Clarence-Smith 1990 [1985]). Na sequência da ditadura militar imposta pelo movimento do 28 de Maio, as tentativas de colonização oficial pelo alto-comissário de Angola Vicente Ferreira (1926-1928) também se revelaram um fracasso. Todos esses planos de colonização seriam interrompidos. Salazar, que viria a ser chefe de governo (1932-1968) e rosto da ditadura portuguesa do Estado Novo, era à época ministro das Finanças e decidiu estender às colónias o aperto das contas públicas, deitando por terra os planos ambiciosos de colonização dirigida e extinguindo a Repartição dos Serviços de Colonização. O crescimento estimado da população branca, 75\% entre 1920 (20.700) e 1940 (36.192), deve-se principalmente à colonização espontânea das cidades e ao crescimento do funcionalismo público (Castelo 2004).

Com a promulgação do Ato Colonial (1930) mudava a visão sobre as políticas de colonização. Com Armindo Monteiro como ministro das Colónias (1931-1935), já não se queria camponeses brancos a reproduzir nas colónias a vida rural portuguesa. E muito menos se queria migrantes desprovidos de capital e qualificações que fossem aumentar o número de brancos pobres, considerados um sinal alarmante do fracasso da obra colonizadora portuguesa. Pretendia-se uma classe empreendedora e independente de pequenos agricultores e trabalhadores urbanos, que cerceasse a influência de uma importante classe não branca nas colónias. Como resultado, na década de 1930 impõem-se apertadas restrições à entrada de migrantes portugueses em Angola e Moçambique: "[s]ó portugueses com bens, cargos de direção, habilitações superiores ou destinatários de 'carta de chamada', garantindo-lhes emprego ou meios de subsistência no destino, podiam fixar-se nas colónias" (Castelo 2017: 71). Para Armindo Monteiro, "[c]olonizar é tratar do negro", "[o] branco, por agora pelo menos, está destinado a ser o dirigente, o técnico, o responsável", "gente desprovida de saber e de capital não faz falta em África", "dessa temos lá milhões" (Monteiro apud Castelo 2004: 162). Essa mudança na política oficial, na prática aprofundava um abismo social já existente entre os colonos brancos e a população negra (Carreira 1977). É no seio dessas mudanças que acontece a ida da futura esposa de Jaime, Maria Adelaide, para Angola, ao serviço da família Ilharco Morgado. O leque das classes sociais brancas amplia-se e ganha matizes, como se verá pela relação entre estas duas famílias.

Maria Adelaide dos Santos chega a Angola por volta de 1930. Adelaide nasceu em 20 de março de 1911 , na aldeia de Escurquela, pertencente ao concelho de Sernancelhe, no distrito de Viseu. Na sua aldeia não existe memória 
de Adelaide: as pessoas mais velhas que ainda vivem na localidade, hoje despovoada pela migração para França e Suíça, nasceram quando ela já estaria a caminho de Angola. Apenas vive na lembrança dos seus filhos e netos e na da família Ilharco Morgado, sua patrona. Adelaide era ama-de-leite de Fernando Veiga Ilharco Morgado, nascido em Coimbra em 1929, quando a família do pequeno ruma a Angola. A família Ilharco Morgado encaixa noutro perfil de colonos que se dirigiram para Angola, vindos de uma posição social mais elevada, gente de negócios e quadros superiores. Adelaide acompanha-os, estabelecendo-se na Caála. A sua breve história de vida até então ditara esse destino. Os seus parentes ainda vivos relatam-nos que ela trabalhava desde menina como criada de servir, na casa de uma "pessoa de família, como se fosse uma escrava", quando terá sido "enganada" por um certo homem que a deixou primeiro grávida e depois com um nado-morto nos braços. Serviram, então, os peitos cheios de leite de Adelaide para amamentar o filho de Maria Pureza e José Ilharco Morgado (ver figura 5).

Foi assim que Adelaide chegou ao Huambo. Continuou como criada de servir na casa da família Ilharco Morgado até que dali saiu para se casar, tendo-se mantido, durante anos, uma estreita ligação entre as famílias Freitas Munheiro e Ilharco Morgado. Maria Pureza e o seu marido foram padrinhos de Maria José Munheiro, primeira filha de Adelaide. Essa filha contounos que a madrinha tinha ascendência aristocrática e quis ensinar-lhe piano. As biografias e as histórias destas famílias têm fortes pontos de contacto, mas têm também muitos abismos. A colonização fez-se com diferenças e complexas relações de classe, "raça" e género. Essas identidades e estruturas sociais não existem separadas, cruzam-se na vida dos indivíduos e dos grupos (Crenshaw 2019). Adelaide e Maria Pureza eram ambas mulheres e brancas numa sociedade colonial, mas uma ocupava uma posição social superior à outra, chamando a atenção para a necessidade de se localizarem diferentes posições de classe, não apenas entre colonizadores e colonizados, mas também no seio de cada um destes grupos

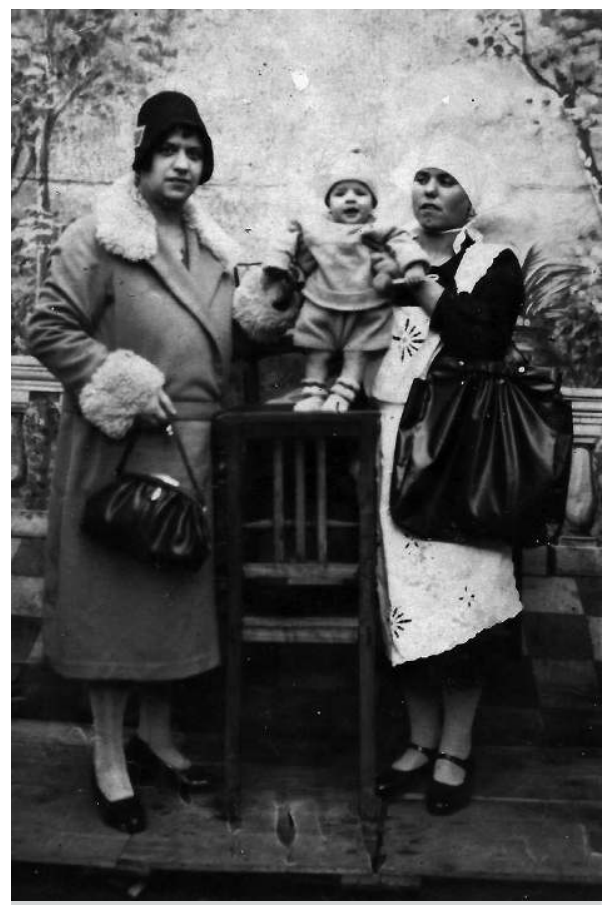

Figura 5 - Adelaide (n. 1911 ), à direita, com Maria Pureza Ilharco Morgado, à esquerda, e com o bebé Fernando Veiga Ilharco Morgado, s/ data. Fonte: arquivo pessoal. 
(Haggis 1990). Não por acaso, foi Maria Pureza quem se tornou madrinha da filha de Adelaide e não o contrário. Escolher para padrinho ou madrinha alguém de posição social superior é comum entre os portugueses mais pobres, com o objetivo de obterem proteção social e económica para os filhos.

Jaime e Adelaide, ela 15 anos mais nova do que ele, casam-se e permanecem na Caála. A sua primeira casa, ainda de madeira e com telhado de capim ao estilo das que os madeirenses reinventaram em Angola, era um pouco afastada da cidade. Depois fizeram uma segunda casa, e uma terceira, já de tijolo e telha, nas terras que Jaime foi comprando ao Estado. Na casa montou a oficina e nas terras fazia cultivo e criava gado. Segundo nos contou a sua filha Maria José, tinha 32 empregados negros, que se ocupavam do trabalho na oficina e nos campos, de onde Jaime colhia trigo, milho e outros cereais. Não os vendia. Serviam para alimentar o pessoal e o gado que usava para puxar as carroças. Era desta atividade, e da oficina, que retirava rendimento, embora nos digam os seus descendentes que não acumulou riqueza. Também nos dizem que para o trabalho da casa não dispunha de empregados. Apenas contava com a lavadeira, negra. O resto do trabalho da casa eram as mulheres - a sua mulher e as filhas - que o faziam, em troca, dizem elas, de "poucos elogios e muita pancada". Apesar de alguns rumores familiares sobre filhos de Jaime com mulheres negras, anteriores ao casamento ou paralelos a este, não obtivemos testemunhos que explicassem melhor essa hipotética descendência.

Esta história familiar vivida em Angola, como tantas outras, não é apenas uma história de colonização, de migração e de exploração racial; é também uma história de violência de género e de patriarcado. Embora exista ampla evidência de que as mulheres brancas atuaram ao lado dos homens brancos enquanto agentes do projeto imperial, beneficiando do privilégio branco e gozando de uma posição de dominação social (Jones 2007), não deixavam de se posicionar, como nota Jenny Coleman, enquanto "membros do sexo 'inferior' no seio da raça dominante" (2012: 63). Nesta posição ambivalente, são simultaneamente vítimas da violência patriarcal e servidoras do processo de colonização dirigida por homens brancos, tal como a historiografia feminista tem dado conta (e.g. Callaway 1987; Jolly 1993).

Adelaide teve cinco filhos, em casa. A primogénita, Maria José Munheiro, nasceu em 18 de outubro de 1936. Por ser a mais velha, e também porque a mãe era doente, viu-se obrigada a ajudar a tratar dos irmãos mais novos, que foram nascendo com pouca diferença de idades. Maria José andou pouco tempo na escola. O pai não queria que estudasse, levando-a para casa para trabalhar.

Em 24 de março de 1951, Maria José, ainda com 14 anos, casa-se com Manuel Abel de Góis. Abel, à data do casamento com 27 anos, tinha nascido na freguesia do Arco de São Jorge, concelho de Santana, ilha da Madeira, em 1 de abril de 1922. A miséria continuava a convidar os madeirenses à fuga da 
ilha. Sabemos que o sogro, que Maria José não chegou a conhecer, deixou os filhos na ilha e partiu para a Venezuela. Anos mais tarde, também o mais velho dessa prole, Abel, se despediu da família e fugiu da ilha com o Circo Ferroni. Foi nos caminhos do circo que chegou a Angola. Depois de abandonar o circo, onde foi trapezista, acabou por se fixar na Caála como padeiro. E foi na padaria que Maria José e Abel se conheceram. O casamento aconteceu pouco depois, com autorização do pai, por Maria José ser ainda menor. Maria José ficou a morar na casa do seu pai na Caála, num anexo independente, até que conseguiu comprar um terreno ao Estado para construir casa própria, pegada à casa do pai. Era pequena, com um terreno onde só havia uma horta e árvores de fruto.

A chegada de Abel e os tempos do início do casamento coincidem com os tempos do pós-Segunda Guerra, época em que se dá "o verdadeiro arranque

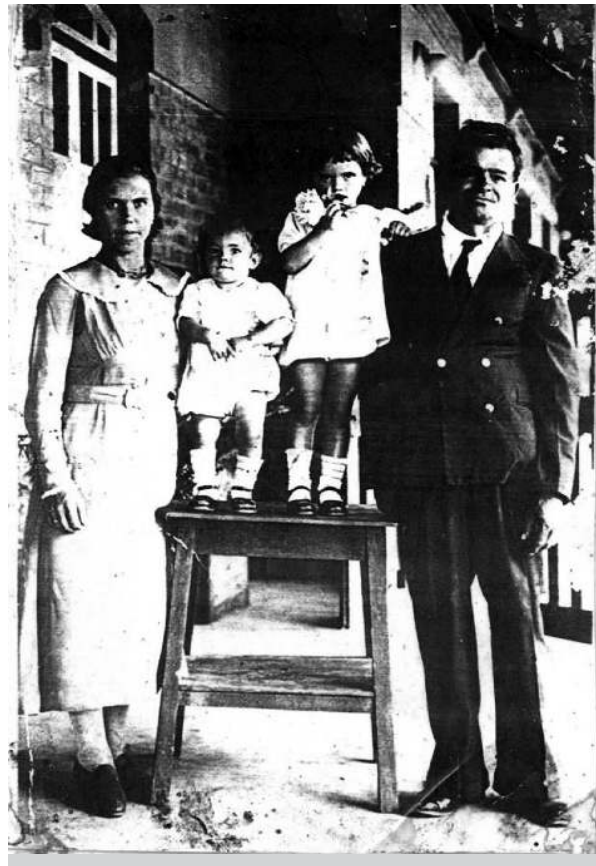

Figura 6 - Adelaide e Jaime de Freitas Moinheiro com os filhos mais velhos, Maria José (n. 1936) e António (n. 1938), Angola, 1939; Adelaide estava já grávida do terceiro filho, João dos Reis (n. 1940). Fonte: arquivo pessoal. da colonização", com a população branca em Angola a aumentar de 44 mil em 1940 para 79 mil em 1950, e 173 mil em 1960 (Castelo 2004: 166). A subida da cotação do café em 1947 foi um incentivo para as migrações para Angola, mas o facto determinante foram as ambições do Estado Novo de legitimar as colónias portuguesas como "províncias ultramarinas" perante o contexto internacional do pós-Guerra. O Estado Novo, que outrora limitara a intervenção direta estatal nos projetos de colonização branca, invertia agora o caminho. Nesse ano de 1947, a emigração para o estrangeiro (ainda maioritariamente para o Brasil) é suspensa por alguns meses para encaminhar os fluxos migratórios para as colónias, ao mesmo tempo que se assiste a um gradual abrandamento das restrições à fixação de portugueses não qualificados em Angola e Moçambique. Partem de novo rumo às colónias muitos migrantes ligados ao setor primário, com baixos níveis de escolaridade e originários de distritos do interior, como Viseu ou Guarda, sobretudo os contingentes recrutados para os colonatos e núcleos de povoamento agrário oficiais (Castelo 2004).

Enquanto se assistia à chegada em massa de novos colonos, Abel e Maria José reproduziam o modo de vida que esta recebera dos seus pais e avós. Entre 
os anos de 1952 e 1974 tiveram seis filhas e três filhos, todos nascidos na Caála. Os mais velhos fizeram aí a escola, mas a maior parte não foi além da 4. ${ }^{a}$ classe. A rede pública escolar era ainda pouco extensa, nesses inícios dos anos 50, apenas se alargando progressivamente à medida que se caminhava para o fim do colonialismo português (Paulo 1999). E ainda que a frequência escolar fosse garantia de mobilidade social ascendente, pelo menos para colonos brancos e alguns negros assimilados, a verdade é que as colónias portuguesas continuavam a registar os maiores índices de analfabetismo de toda a África Austral. ${ }^{10}$ Não eram muitos os negros que frequentavam a escola. Embora o ensino fosse misto, o assento no ensino normal estava reservado aos "cidadãos" brancos e negros assimilados, ficando a educação dos "indígenas" (maioria da população negra) entregue principalmente às missões católicas e ao ensino rudimentar (pelo menos até 1964, data em que este ensino é extinto). As imagens do convívio inter-racial nas escolas fazem mais parte da propaganda dos últimos anos do regime do que das memórias de Maria José. No seu tempo, a socialização escolar estava marcada por um regime de segregação racial que limitava a educação do indígena à "aquisição de hábitos e aptidões de trabalho" (Paulo 1999: 316). Só mais tarde, no contexto dos processos de luta anticolonial, e sob a chancela do ideário luso-tropicalista, a facultação aos africanos de um tipo de mobilidade social por via da adesão à frequência escolar toma uma expressão mais evidente.

Na sua memória, Maria José vivia alheada deste mundo. Diz-nos que não tinha empregados e que ela própria tinha de trabalhar como lavadeira e como criada de limpeza nas casas de outras famílias brancas, juntamente com as trabalhadoras negras. Ocorre-nos que Maria José prefira lembrar-se da sua história de vida como uma história de sacrifício, e não como uma história de privilégio. Tinha os planos para o futuro bem definidos: no terreno da sua propriedade tinha já nove lotes divididos para distribuir por cada um dos filhos, para que neles pudessem fazer as suas habitações. Ali tinha casa e futuro.

\section{GUERRA, “RETORNO” E DISPERSÃO}

Até aos últimos tempos do colonialismo português, Maria José e a maioria dos seus filhos continuaram a viver na Caála. Porém, os seus irmãos mais novos seguiram o caminho do desenvolvimento urbano de Angola. Repetia-se a história do seu pai, Jaime, que abandonara a Chibia rumo à Caála, seguindo as novas oportunidades trazidas pelo desenvolvimento da colonização no

10 Segundo dados publicados pela UNESCO entre 1955 e 1966, através do World Survey of Education, Angola e Moçambique registavam as mais baixas taxas de escolarização em África e com índices de analfabetismo que ultrapassavam os 95\% (Paulo 1999: 321). 
interior. Agora o movimento era rumo às cidades, então em grande desenvolvimento (Domingos e Peralta 2013).

O choque da guerra, sentido em 1961, seria o grande impulsionador da implementação de um colonialismo efetivo e modernizador por parte de Portugal, ainda que extemporâneo em relação aos rumos que a história tinha tomado no continente africano. Ainda antes da deflagração dos conflitos armados, o regime começara a dar alguns passos para evidenciar o caráter desenvolvimentista do colonialismo português perante as instâncias internacionais que exortavam Portugal a descolonizar. Os Planos de Fomento passaram a afetar verbas significativas ao "Ultramar", pondo fim a décadas de negligência neste domínio (Oliveira 2017). Predominantemente orientados para infraestruturas de apoio à exploração económica ou para esquemas de colonização branca, estes planos deveriam resultar como importantes travões à irradiação dos focos de contestação nacionalista em África. Não puderam, contudo, evitar a materialização da ameaça que irrompia desde a independência do vizinho Congo ex-belga, em 1 de julho de 1960.

Junto das populações das colónias continuava a reproduzir-se a narrativa do excecionalismo da presença portuguesa em África e não se vislumbrava qualquer solução política para a questão colonial. As pressões diplomáticas das Nações Unidas sobre Portugal, iniciadas em 1956, intensificaram-se no quadro da Declaração sobre a Concessão da Independência aos Países e Povos Coloniais, enquanto a diplomacia portuguesa insistia na tese de que não possuía territórios não autónomos, apenas províncias (Almada e Santos 2011). ${ }^{11}$ A oposição africana ao colonialismo português, nomeadamente pelo Movimento Anticolonialista, criado em 1957, nunca encontrou abertura ao diálogo por parte do governo. Em março de 1961, os ataques da UPA nas fazendas do Norte de Angola não só ditam o início de um ciclo de guerras de libertação nacional, em Angola (1961), Guiné-Bissau (1963) e Moçambique (1964), conhecidas em Portugal como Guerra Colonial (1961-1974), mas também determinam um crescimento da população branca nas colónias. No curto mas incisivo mandato de Adriano Moreira como ministro do Ultramar (1961-1962) são aprovadas importantes medidas de estímulo ao povoamento branco, nomeadamente a instituição da liberdade de circulação e fixação (Decreto n. ${ }^{\circ} 44.171$, de 1 de fevereiro de 1962). Novos residentes portugueses continuam a instalar-se em Angola (sobretudo) e Moçambique ao longo dos 13 anos de guerra. A presença de uma massa populacional residente na ordem dos 500 mil indivíduos (dos quais apenas 35\% tinham nascido nas colónias, segundo Castelo 2017: 84), junto com a permanência de um significativo corpo expedicionário em África (nunca abaixo dos 80 mil militares metropolitanos entre 1967 e 1973, muitos 
deles acompanhados de familiares, segundo Oliveira 2017: 56), foram fatores determinantes para um surto de desenvolvimento económico nas colónias. As colónias africanas passam a ser lugares de vanguarda da modernidade portuguesa, com níveis de vida e taxas de crescimento económico incomparáveis aos da metrópole (em particular em Angola). Nessa economia em desenvolvimento, mesmo com diferenças de posição social entre a população branca, a fronteira racial continuava a ser uma marca determinante da vida social. Mesmo que não possuísse qualificações ou recursos financeiros, um imigrante branco podia esperar sempre "não cair abaixo de um nível económico que estava completamente fora do alcance da grande maioria dos africanos" (Heimer 1980: 21).

O crescimento económico corre a par com a galopante urbanização do território. Com a implementação de grandes projetos de renovação urbana impulsionados pela Direção de Serviços de Urbanização e Habitação, ${ }^{12}$ que deram uma fachada modernista principalmente a cidades como Luanda ou Lourenço Marques, as cidades coloniais tornaram-se eixos de modernização e de desenvolvimento capitalista das colónias (Peralta e Domingos 2018). Este processo de crescente urbanização contrasta com a retórica inicial das aspirações, nunca conseguidas, à reprodução em África da vida rural portuguesa. Assente em lógicas de segregação espacial, como aquelas que separavam a "cidade de cimento" dos "musseques", este processo de urbanização evidencia também o contraste entre a propaganda do regime em torno da constituição na África portuguesa de sociedades multirraciais harmoniosamente integradas e as muitas divisões de "raça" e classe que marcavam a realidade colonial.

É neste contexto de modernização que os filhos de Jaime deixam a Caála para procurarem o seu modo de vida na capital da Lunda, em Saurimo, então chamada vila Henrique de Carvalho (elevada a cidade em 1956). A cidade estava localizada na região diamantífera que correspondia ao território onde a Diamang - Companhia de Diamantes de Angola exercia o seu poder. Esta empresa de capitais mistos (Portugal, Bélgica, Estados Unidos, Inglaterra e África do Sul), tal como tantas outras, recrutava trabalhadores forçados (Varanda 2017), ao abrigo do estatuto do indigenato, entretanto abolido como uma das respostas à guerra de libertação nacional de Angola. Nesses anos finais do colonialismo português, Henrique de Carvalho vivia um grande ímpeto modernizador, sobretudo após a abertura, em 1963, de uma base aérea militar, que funcionava como um importante posto estratégico de defesa do território contra potenciais invasivas procedentes do vizinho Congo. É aí que os filhos de Jaime se estabelecem. Como o pai, vão trabalhar como mecânicos, já não de carroças, mas de automóveis, e na construção civil.

12 Em 1944 foi criado o Gabinete de Urbanização Colonial, posteriormente designado Gabinete de Urbanização do Ultramar, de 1951 a 1957, e Direção de Serviços de Urbanização e Habitação, entre 1957 e 1974. 
Da Madeira para a Húla, da Huíla para o Huambo, do Huambo para a Lunda, sempre à procura de um modo de vida, os percursos que marcam esta família continuam a ser os de migrantes económicos. A diferença entre estes percursos e os percursos paralelos que terão tido os Moinheiro que foram para o Brasil ou para a Nova Inglaterra, como tantos outros portugueses, é que a sua posição social é a de cidadãos da potência colonial. Mas, também entre os portugueses estabelecidos nas colónias, vemos que as posições sociais de partida e o género, além da "raça", têm um grande peso nas escolhas possíveis e nos percursos de cada pessoa. Enquanto os percursos de vida dos homens numa sociedade marcada pela dominação masculina eram mais autónomos, as escolhas disponíveis para as mulheres eram mais limitadas, embora tanto a autonomia como a limitação variassem conforme a classe e a "raça" de cada um. Maria José, por ser mulher, teve o seu destino ligado à terra onde nasceu e ao marido que aí se estabeleceu como agricultor. Ainda assim, a sua posição na sociedade colonial seria mais vantajosa do que a das mulheres negras, como a própria reconhece. Apesar de achar que "miséria é sempre miséria, sejam brancos ou pretos a governar", Maria José não deixa de ser veemente ao culpabilizar os homens brancos pela sua ganância em "fazer riqueza, apanhar tudo o que é dos outros", e pelos abusos que cometeram. Mas a sua crítica aos homens não se limita às questões económicas e do trabalho, estendendo-se a questões de exploração sexual e violência de género: "Faziam pouco das pessoas, faziam filhos, deixavam-nas ficar com os filhos, abandonavam-nas! Para quê tanto mulatinho abandonado? Isso não se faz!” Tal como é analisado por Stoler (2002) na sua investigação sobre as colónias holandesas, as relações entre os colonos e as populações originárias dos territórios colonizados, em particular as relações sexuais dos colonos homens com as mulheres locais, embora sujeitas a variações, visam genericamente preservar a supremacia racial dos europeus. Daí os filhos abandonados de que nos fala Maria José. Com efeito, é comum haver na biografia dos portugueses mestiços, ou dos seus pais ou avós, um momento de abandono pelo pai branco, ou a retirada dos filhos à mãe negra para serem criados pela família europeia.

Quanto aos homens, a sua relativa autonomia estava profundamente limitada pelas respetivas posições de classe, mesmo entre colonos de origem europeia e brancos. Enquanto os irmãos de Maria José tiveram os seus percursos de vida determinados por opções económicas, já o seu “irmão-de-leite", pertencente a uma família mais bem posicionada socialmente, teve disponível um âmbito de ação mais vasto e menos vulnerável às condicionantes da história e da política. Com efeito, descobrimos que Fernando Ilharco Morgado, o "menino" que Adelaide amamentou, após a sua infância na Caála, ainda fez o liceu em Angola e de lá saiu para se formar como engenheiro civil na Universidade do Porto. Foi também poeta, colaborou com as revistas Vértice e Seara Nova, esteve clandestino, foi perseguido pela polícia política portuguesa, 
a PIDE, exilou-se em França em 1964, viveu no Brasil, e faleceu em Portugal, em 2014 (Stoenesco 2014). A sua posição social mais favorecida permitiu-lhe ter acesso a uma formação superior, mas a sua opção política empurrou-o para o exílio $1 \mathrm{l}$ anos antes de os filhos de Adelaide se verem obrigados a decidir se ficavam em Angola ou partiam para a ex-metrópole. ${ }^{13}$

Em todos os casos, a história da colonização e da descolonização guardou para os homens de uma geração a guerra (ou a deserção e exílio) como destino. Os irmãos e genros mais velhos de Maria José foram recrutados pelo exército português e participaram na guerra contra os movimentos de libertação nacional angolanos. No Natal de 1962, o irmão António Munheiro estava a cumprir serviço militar, quando lhe foi enviada uma foto da família (ver figura 7). Duas realidades paralelas e paradoxais - a modernização e a guerra - conviviam aparentemente de forma harmoniosa, sem que um questionamento dos seus pressupostos antinómicos se colocasse sob os olhos desta família ou de tantas outras que acreditavam na perenidade do império português. Doutrinados nos mitos do regime, ludibriados pela censura e fascinados pelo frenesim da modernização colonial, os portugueses de Angola viviam alheios à vaga internacional da descolonização iniciada com a independência da Índia face ao império britânico em 1947. Viviam também, na sua maioria, alheios às

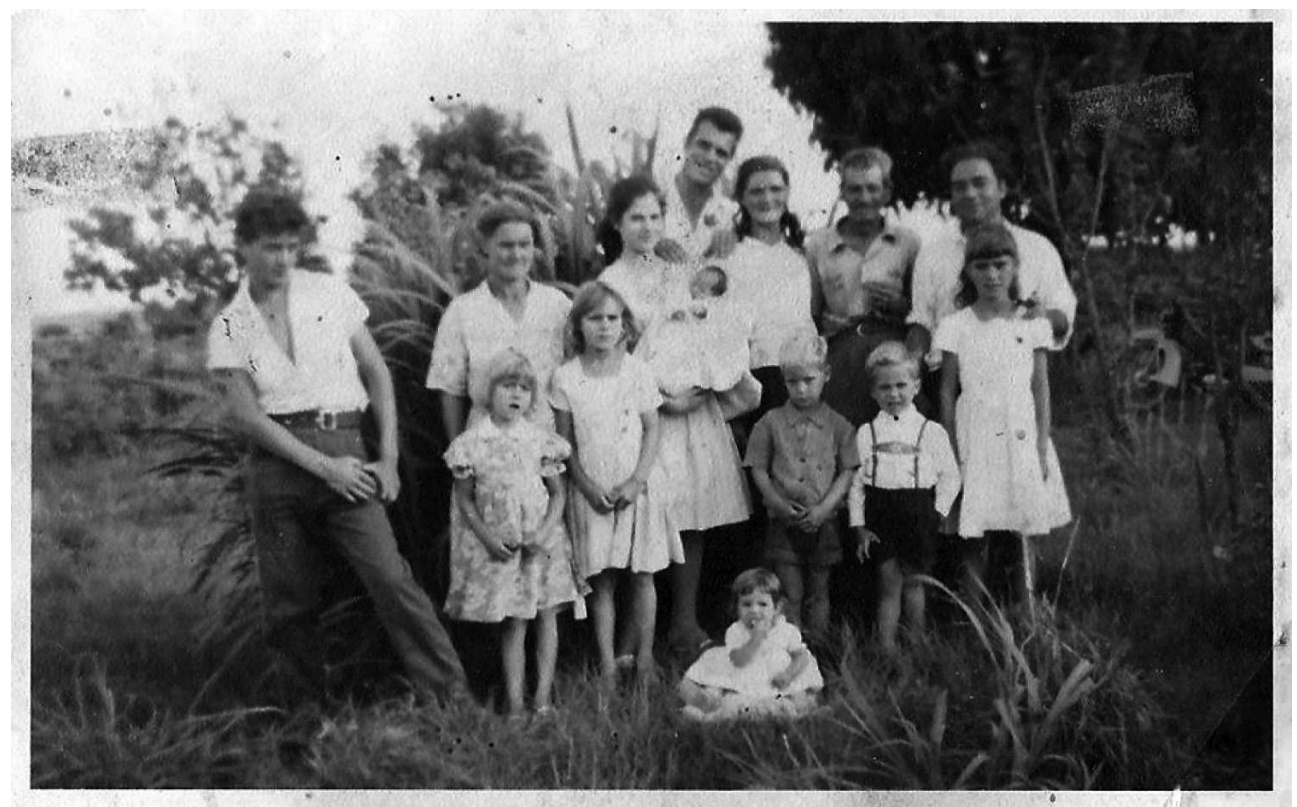

Figura 7 - Maria José (n. 1936), pais Jaime (n. 1896) e Adelaide (n. 1911), irmãos, cunhado, filhos e sobrinhos mais velhos em Angola, 1962. Fonte: arquivo pessoal.

13 A história de Fernando Ilharco Morgado foi completada através de entrevista à filha do próprio, Gabriela, residente em Lisboa. 
reivindicações dos movimentos de libertação nacional africanos em Angola (FNLA, MPLA e UNITA) ${ }_{1}^{14}$ cujos atos classificavam sumariamente como terroristas. A guerra era no mato, longe das cidades de cimento onde cada vez mais viviam as populações colonas, antigas ou recentes.

Não é, por isso, de espantar que Maria José nos tenha dito que "a guerra foi depois”. Quando se dá o 25 de Abril de 1974, recebe com indiferença a euforia dos "pretos", como lhes chama. Na sua memória, o sobressalto da guerra chega somente em 1975, quando começam os conflitos armados entre a FNLA, o MPLA e a UNITA. O Acordo de Alvor, assinado entre o governo português e os três movimentos de libertação em 15 de janeiro de 1975, previa que a independência de Angola, no dia 11 de novembro desse ano, fosse liderada pelas três forças políticas e com unidade entre as populações negras, brancas e mestiças. No entanto, os princípios desse acordo acabaram por ser gorados e os três movimentos de libertação, apoiados nos seus alinhamentos internacionais, prosseguiram uma luta pelo poder (Henriksen 1976), dando início à guerra civil de Angola. Como a UNITA tinha o seu quartel-general no Huambo, a guerra mais intensa a norte acaba por se propagar ao Sul. Quando Maria José se deu conta, a guerra chegara à porta da sua casa. Subitamente não havia ninguém. Todos tinham fugido. As lojas estavam vazias. Não havia nada para comprar para comer.

Em julho de 1975, os irmãos de Maria José e as suas famílias vêm fugidos de Henrique de Carvalho, onde viviam e trabalhavam havia muitos anos. Chegam debaixo de fogo e estabelecem-se em sua casa, na Caála. Trazem máquinas, mobílias e bens pessoais, tudo estacionado no seu quintal. Logo de seguida, a família prepara a fuga. Tinham o plano inicial de fugir por terra, rumo à então Rodésia e depois à África do Sul, territórios onde vigorava a supremacia racial branca. Mas Francisco, o mais novo dos filhos de Jaime, que se havia casado com Dina, uma mulher mestiça, não aceita ir para uma terra onde a sua mulher e filhos iriam ser discriminados pelo Apartheid. Invertem a rota para oeste, rumo ao litoral. A saída seria pelo Atlântico. A fuga acaba por ser organizada pelo companheiro da sua filha Terezinha, o sargento Correia, um português em serviço militar permanente em Angola, que, embora já fosse casado na metrópole, havia constituído (nova) família em África. Neste caso, a nova família, constituída com uma angolana branca, foi assumida após o retorno do militar para a ex-metrópole, com a oficialização do casamento entre ambos. Não terá sido este o desfecho de muitas destas uniões com mulheres negras, que resultaram em inúmeras histórias de filhos mestiços abandonados em África pelos militares portugueses (Gomes 2018).

14 A partir da década de 1950 foram-se estruturando os movimentos de libertação nacional africanos em Angola: a UPA/FNLA (Frente Nacional de Libertação de Angola, cuja origem remonta à União das Populações do Norte de Angola de 1954), o MPLA (Movimento Popular de Libertação de Angola, 1956) e a UNITA (União Nacional para a Independência Total de Angola, 1966). 
O carro da tropa foi buscá-los para os levar para o aeroporto de Nova Lisboa/ Huambo e de lá para Portugal, através da ponte aérea organizada pelo governo português. Maria José não queria vir. Não queria deixar a casa para trás. Mas tinha medo, por si e pelos seus filhos e netos, que já então os tinha. Acabou por ceder, mas diz-nos que pensava voltar depois da independência, prevista para 1 l de novembro, "que as coisas iriam acalmar". E é assim que Maria José, sua mãe, irmãos e cunhados, filhos, sobrinhos, genros e netos vão partindo em aviões conforme a rádio vai anunciando a vez de cada agregado familiar.

Os cinco filhos de Jaime e Adelaide não se queriam separar, mas não conseguiram evitá-lo. Quase todos partiram rumo a Portugal, para diferentes destinos. Mas, à última hora, António Munheiro decidiu ficar. Angola era a sua terra, aí continuou com a mulher e filhos, e aí nasceram os seus netos. A sua família iria viver as mudanças do novo país, sofrer a guerra civil, passar por progressos e recuos, e seguir a pressão das suas migrações internas, rumo a Luanda. António Munheiro passou os últimos anos da sua vida na capital angolana, tendo aí falecido em 2016. A sua decisão de ficar, embora minoritária entre os portugueses de Angola, não é invulgar nas famílias mais enraizadas na ex-colónia, havendo casos de pessoas que ficaram e outras que regressaram após um período na África do Sul, e ainda outras que se estabeleceram definitivamente neste país.

Maria José chegou a Lisboa às 12 horas do dia 12 de setembro de 1975. Não trouxe nada, só a roupa do corpo. Diz-nos que ficou tudo no seu quintal, na Caála, e que o ouro foi confiscado no aeroporto. O dinheiro não valia a pena trazer, porque não o trocavam. No aeroporto de Lisboa foi uma confusão. "Tudo ao monte", como conta: "Brancos, pretos, mulatos, malas, sacos, cobertores, e crianças, muitas crianças". Maria José não sabia o que fazer. Os filhos pequenos e os netos, todos a dizer-lhe que tinham fome, mais desorientados do que ela. Só se lembra da assistente social que lhes veio trazer uma tigela de sopa. E que o IARN lhes deu cinco contos à cabeça para se fazerem à vida. ${ }^{15}$ Passadas quatro horas estavam de novo dentro de um avião rumo à ilha da Madeira, para serem acolhidos pela família que o seu marido, Abel, tinha deixado para trás quase 30 anos antes, para se aventurar pelo mundo com o Circo Ferroni. Foi a primeira vez que Maria José saiu de Angola, onde nasceu.

15 O Instituto de Apoio ao Retorno de Nacionais (IARN) foi a agência estatal portuguesa encarregada da integração desta população "nacional”, ou seja, com acesso à cidadania portuguesa por serem naturais da ex-metrópole ou descendentes. O Decreto-Lei n. ${ }^{\circ}$ 308-A/75, de 24 de junho, retirou, com efeito após a independência dos novos Estados, a cidadania à maioria das pessoas naturais das antigas colónias. Sem fazer referência à cor da pele, o decreto-lei excluiu da cidadania portuguesa, sem qualquer direito de opção, a esmagadora maioria dos "não brancos". Os "cinco contos" referem-se a cinco mil escudos, ou cerca de 25 euros, embora correspondessem a cerca de 700 euros em 1975, tendo em conta as taxas de variação do índice de preços no consumidor $(<$ https://www.ine.pt/xportal/xmain? xpid=INE \&xpgid=ipc > última consulta em maio de 2020). 
Estiveram um ano na Madeira, Maria José, Abel e os seus seis filhos mais novos. Este ano lá passado não deixou saudades a Maria José. O acolhimento por parte da família do marido não terá sido o melhor. Diz que teve de trabalhar duro, de enxada, para receber da sogra um magro apoio à subsistência. Dá-se um embate cultural entre cidadãos da mesma nação e o encontro é caracterizado pelo estranhamento mútuo. Conta-nos Maria José que a sogra demorou muito tempo até se convencer de que os netos não eram negros, pois acreditava que, por terem nascido em África, não poderiam ter a pele branca. Chegou até a esfregar-lhes a pele com um pano húmido convencida de que a sua negritude acabaria por se revelar. Se bem que o acolhimento por parte da família do marido tivesse sido um recurso importante no primeiro socorro após o retorno, parece que está longe de ter sido motivado pelo sentido de solidariedade nacional que alguns analistas indicam como fator determinante para a integração dos portugueses retornados na metrópole (Peralta 2019). ${ }^{16}$

O filho José, o mais velho dos solteiros, foi o primeiro a fugir do isolamento insular, conseguindo depois trazer a restante família para o continente. Acabam por se estabelecer em Santarém, com o auxílio do IARN. A escolha de Santarém é ditada por Ermelinda, irmã de Maria José que, depois de uma passagem pela Azambuja, onde a família do marido tinha ligações, se estabelece no concelho escalabitano. O marido de Ermelinda era alfaiate e ainda em Angola estava numa situação social melhor do que a da família da cunhada, formada por lavradores. Estes capitais sociais influenciaram profundamente a respetiva integração. Quando vieram para Portugal, Ermelinda e o marido ainda estiveram em habitações providenciadas pelo Estado, mas depois conseguiram comprar um terreno na Romeira, zona rural de Santarém, embora nunca tenham conseguido voltar ao nível de vida que tinham em Henrique de Carvalho. Maria José, Abel e os filhos menores continuaram em alojamentos provisórios do Estado, em Santarém, num longo ciclo de pobreza e de vulnerabilidade social que afetou principalmente os filhos mais novos. Tendo sido um acontecimento profundamente disruptivo, o retorno não foi para todos igual. Os que já ocupavam uma posição social mais baixa antes da vinda foram aqueles cuja situação de vida mais se deteriorou em Portugal e que mais dificuldade de integração tiveram (Hoefgen 1985).

Os Moinheiro da Caála dispersam-se: Angola, Portugal (Santarém, Aveiro, Algarve, Almada), Brasil, Califórnia. Foram muitos e diversos os percursos que se delinearam. Jaime, pai de Maria José, por ter falecido antes do "retorno", ficou sepultado em Angola, na Caála. A mãe, Adelaide, morreu pouco depois

16 Refiram-se, por exemplo, as opiniões de António de Almeida Santos, ministro dos Negócios Estrangeiros (maio de 1974 a agosto de 1975) e Amândio de Azevedo, secretário de Estado para os Retornados (janeiro-julho de 1976), sobre a importância da solidariedade da população metropolitana no acolhimento aos retornados. 
de ter chegado a Portugal e não chegou a rever a terra onde nasceu, no distrito de Viseu, acabando sepultada no cemitério da Romeira, Santarém. Francisco Munheiro, irmão mais novo de Maria José, também seguiu outro destino: ainda esteve em Portugal, mas logo que teve oportunidade rumou ao Brasil com a sua mulher e filhos, onde se estabeleceu até hoje. João dos Reis Munheiro fixou residência em Aveiro. As três filhas mais velhas de Maria José, que já eram casadas, também seguiram os seus próprios destinos. Uma delas, Maria Filomena, irá para São Jorge, nos Açores, de onde era originária a família do marido, mas já com destino traçado para partirem para a Califórnia - o que sucederia passado pouco tempo, seguindo a rota açoriana para os EUA, traçada por muitas gerações de migrações transatlânticas. Dez anos mais tarde, Isabel irá juntar-se à irmã Filomena na Califórnia, aproveitado o contacto familiar já existente. Tempos de clandestinidade foi o que estas luso-angolanas emigradas nos Estados Unidos viveram até se conseguirem estabelecer legalmente. Os filhos e netos aí nascidos já são cidadãos norte-americanos.

Maria José Munheiro, a mais velha dos Moinheiro da Caála por nós entrevistados, teve duas dezenas de netos, duas dezenas de bisnetos e três trinetos, espalhados por três continentes. Fazem parte da diáspora da descolonização portuguesa. Como analisou Pires (1987), os migrantes de segunda e terceira gerações nascidos em África eram aqueles que mais dificuldades tinham em integrar-se em Portugal. Ao contrário dos "retornados" strictu sensu, que se restabeleciam preferencialmente nas suas regiões de origem, os descendentes da colonização mais antiga não tinham geralmente laços familiares e redes de acolhimento em Portugal, ficando assim mais dependentes dos mecanismos estatais de integração. Eram, por isso, os que mais tendiam à (re)migração para outros destinos, nomeadamente para o Brasil ou África do Sul, sociedades com pontos de contacto com as ex-colónias, mas também para outros destinos da migração laboral portuguesa, como os Estados Unidos ou a Venezuela.

\section{CONCLUSÕES}

Tal como muitas outras famílias chegadas a Angola no final do século XIX, os Moinheiro da Caála fazem parte de uma história mais vasta de migrações e dispersão que marcou não só todo o curso do império português, mas também o mundo criado pelos impérios coloniais europeus. No cerne da sua micro-história estão diversas mobilidades e deslocamentos motivados por razões de índole económica: pessoas que partem dos seus locais de origem, ou de outros onde se estabeleceram, sempre à procura de um lugar na economia, um lugar que lhes permita ter casa, trabalho, filhos. Mesmo quando a sua situação é economicamente mais favorável, voltam muitas vezes a deslocar-se para garantir o nível de vida adquirido ou para o melhorar, sempre respondendo às flutuações do sistema económico em que se inserem e às demandas e oportunidades criadas 
pela política interna e pela geopolítica. É essa a lógica que orienta, também, as migrações da família que estudámos: da Madeira para Angola, respondendo aos planos de colonização estatais para fugir à carência económica do arquipélago; dentro de Angola, partindo do Sul, rumo ao Huambo e a muitos outros pontos da colónia, respondendo às sucessivas novas oportunidades oferecidas pelo desenvolvimento da colonização e pela urbanização do território; de Angola para a dispersão, rumo a Portugal mas também aos destinos da emigração portuguesa, aos EUA ou ao Brasil, respondendo ao "retorno" forçado pela descolonização. Enquanto participantes num sistema colonial dependente do povoamento metropolitano, o que preside às suas escolhas é a busca de casa e modo de vida para a família, e não as lógicas das narrativas nacionais assentes em ideias de pátria ou soberania.

O perfil social destas pessoas é o de migrantes económicos, e a família é a célula da sua reprodução social. Nessa condição, ocupam uma posição social frágil, muito suscetível às flutuações económicas e às contingências políticas. Esta sua fragilidade existencial, não obstante, é compensada quer ao nível material, quer ao nível simbólico, pelo privilégio branco. Fazem, à chegada, parte da sociedade dos colonos, que subalterniza as sociedades locais dominadas pelo Estado colonial. Posteriormente, e à medida que a sociedade colonial se unifica pela integração subalterna e forçada da população negra, continuam a ocupar uma posição intermédia. Ainda assim, subsiste o abismo social que o colonialismo cria entre elas e as populações africanas negras. Mesmo aqueles brancos que ocupavam uma posição mais vulnerável no sistema colonial, como a família Freitas Moinheiro, guardam para si a compensação de fazerem parte do mundo dos brancos.

\section{BIBLIOGRAFIA}

ALMADA E SANTOS, Aurora, 2011 , "A ONU e as resoluções da Assembleia Geral de dezembro de 1960", Relações Internacionais, 30: 61-69.

ANDRADE, Tonio, 2011 , "A Chinese farmer, two African boys, and a warlord: toward a global microhistory". Journal of World History, 21 (4): 573-591.

BASTOS, Cristiana, 2008, "Migrants, settlers and colonists: the biopolitics of displaced bodies”, International Migration, 46 (5): 27-54.

BOURDIEU, Pierre, 1991, "First lecture. Social space and symbolic space: introduction to a Japanese reading of distinction", Poetics Today, 12 (4): 627-638.

BURKITT, Ian, 2008, Social Selves: Theories of the Social Formation of Personality. Londres, Sage

Publications. 
CALlaWAY, Helen, 1987, Gender, Culture and Empire: European Women in Colonial Nigeria. Basingstoke, Palgrave Macmillan.

CARreIrA, António, 1977, Angola, da Escravatura ao Trabalho Livre: Subsídios para a História Demográfica do Século XVI até à Independência. Lisboa, Arcádia.

CASTELO, Cláudia, 2004, "Um segundo Brasil ou um terceiro Portugal: políticas de colonização branca da África portuguesa (1920-1974)", Travessias: Revista de Ciências Sociais e Humanas em Lingua Portuguesa, 4/5: 155-180.

CASTELO, Cláudia, 2017, "Migração colonial para Angola e Moçambique (séculos XIX-XX)", em Elsa Peralta, Bruno Góis e Joana Oliveira (orgs.), Retornar: Traços de Memória do Fim do Império. Lisboa, Edições 70, 63-84.

CLARENCE-SMITH, William Gervase, 1990 [1985], O Terceiro Império Português (1825-1975). Lisboa, Teorema.

COLEMAN, Jenny, 2012, “The 'inferior' sex in the dominant race: feminist subversions or imperial apologies?", Feminist Review, 102: 62-78.

COSME, João, 2007, "Nótulas sobre a emigração madeirense na segunda metade do século XIX”, Islenha, 41: 41-58.

CRAPANZANO, Vincent, 1980, Tuhami: A Portrait of a Moroccan. Chicago/Londres, The University of Chicago Press.

CRENSHAW, Kimberlé, 2019, On Intersectionality: Essential Writings. Nova Iorque, The New Press.

DOMIngOs, Nuno, e Elsa PERALTA (orgs.), 2013, Cidade e Império: Dinâmicas Coloniais e Reconfigurações Pós-Coloniais. Lisboa, Edições 70.

FERREIRA, Jo-Ann, 2006, "Madeiran Portuguese migration to Guyana, St. Vincent, Antigua and Trinidad", Portuguese Studies Review, 14 (2): 63-85.

GINZBURG, Carlo, 1993, "Microhistory, two or three things that I know about it", Critical Inquiry, 20 (1): 10-35.

GOMES, Catarina, 2018, Furriel não é Nome de Pai: Os Filhos que os Militares Portugueses Deixaram na Guerra Colonial. Lisboa, Tinta-da-China.

HAGGIS, Jane, 1990, "Gendering colonialism or colonising gender? Recent women's studies approaches to white women and the history of British colonialism", Women's Studies International Forum, 13 (1-2): 105-115.

HEIMER, Franz-Wilhelm, 1980, O Processo de Descolonização em Angola, 1974-1976. Lisboa, A Regra do Jogo.

HENRIKSEN, Thomas H., 1976, "People's war in Angola, Mozambique, and Guinea-Bissau", The Journal of Modern African Studies, 14 (3): 377-399.

HOEFGEN, Lynn, 1985, The Integration of Returnees from the Colonies into Portugal's Social and Economic Life. Gainesville, University of Florida, tese de doutoramento.

JOLLY, Margaret, 1993, "Colonizing women: the maternal body and empire", em Sneja Gunew e Anna Yeatman (orgs.), Feminism and the Politics of Difference. St. Leonards, Allen and Unwin, 103-127.

JONES, Cecily, 2007, Engendering Whiteness: White Women and Colonialism in Barbados and North Carolina, 1627-1865. Manchester, Manchester University Press.

LEVI, Giovanni, 1991, "On microhistory”, em Peter Burke (org.), New Perspectives on Historical Writing. University Park, PA, Penn State University Press, 97-1 19.

MAGNÚSSON, Sigurđur Gylfi, 2003, “The singularization of history: social history and microhistory within the postmodern state of knowledge", Journal of Social History, 36 (3): 701-735. 
MEDeiros, Carlos Alberto, 1976, A Colonização das Terras Altas da Huíla (Angola). Lisboa, Centro de Estudos Geográficos e Instituto de Altos Estudos.

MENDONÇA, Leandro de, 1951, "A colonização madeirense no Sul de Angola", Das Artes e da História da Madeira, I (5): 35-36.

MEneZES, Mary Noel, 1995, The Portuguese of Guyana: A Study in Culture and Conflict. Anand (Gujarat), Anand Press.

MINTZ, Sidney W., 1974 [1960], Worker in the Cane: A Puerto Rican Life History. Nova Iorque, W.W. Norton.

OLIVEIRA, Pedro Aires, 2017, "As condições políticas e sociais da descolonização", em Elsa Peralta, Bruno Góis e Joana Oliveira (orgs.), Retornar: Traços de Memória do Fim do Império. Lisboa, Edições 70, 45-62.

PAINTER, Nell Irvin, 2010, The History of White People. Nova Iorque, W. W. Norton.

PAULO, João Carlos, 1999, “Da 'educação colonial portuguesa' ao ensino no ultramar”, em Francisco Bethencourt e Kirti Chaudhuri (orgs.), História da Expansão Portuguesa, vol. 5. Lisboa, Círculo de Leitores, 304-333.

PERALTA, Elsa, 2019, "The return from Africa: illegitimacy, concealment, and the nonmemory of Portugal's imperial collapse”, Memory Studies, pré-publicação online, DOI: 10. $1177 / 1750698019849704$.

PERALTA, Elsa, e Nuno DOMINGOS, 2018, "Lisbon: reading the (post-)colonial city from the nineteenth to the twenty-first century", Urban History, 46 (2): 246-265.

PIRES, Rui Pena, 1987, Os Retornados: Um Estudo Sociográfico. Lisboa, Instituto de Estudos para o Desenvolvimento.

SÈVE, Lucien, 2008, Penser avec Marx Aujourd'hui. II: L'Homme? Paris, La Dispute.

STOENESCO, Dominique, 2014, “'O peso da luz' de Fernando Ilharco Morgado”, Luso Jornal, s. II, 181: 12 .

STOLER, Ann Laura, 2002, Carnal Knowledge and Imperial Power: Race and the Intimate in Colonial Rule. Berkeley, University of California.

TILLY, Louise A., e Miriam COHEN, 1982, "Does the family have a history? A review of theory and practice in family history”, Social Science History, 6 (2): 131-179.

TURNER, Victor, 1960, "Muchona, the horner", em Joseph B. Casagrande (org.), In the Company of Man: Twenty Portraits of Anthropological Informants. Nova Iorque, Harper Torchbooks, 333-356.

VARANDA, Jorge, 2017, "Diamang: a dupla face do colonialismo português", Revista História, Jornal de Notícias, 8: 8-35.

\author{
Receção da versão original / Original version \\ Receção da versão revista / Revised version \\ Aceitação / Accepted \\ Pré-publicação online / Pre-published online
}

$2018 / 04 / 24$

$2019 / 07 / 31$

$2019 / 10 / 15$

$2020 / 07 / 16$ 